\title{
ECONOMY OF MANA
}

\section{Where to next?}

\author{
Kiri Dell* \\ Nimbus Staniland ${ }^{\dagger}$ \\ Amber Nicholson ${ }^{\ddagger}$
}

\begin{abstract}
Writings on traditional Māori economies have highlighted the value system that philosophically underpins them and the relational nature of trading interactions. Further, the significance of mana in sustaining economic relationships has been emphasised, leading to the concept of an "economy of mana". In this paper, we explore traditional Māori economies, the concept of mana and the limited exploration of an economy of mana in order to propose future research directions for Māori economic research. Despite a wealth of literature focusing on the past, and emerging research investigating the modern Māori economy, we argue there is yet to be an articulate visioning of Māori economic futures built upon an economy of mana. It is our contention that enhancing our understanding of where we want to go will ultimately support the development of alternative economies that will better provide for Māori aspirations in cultural, social and economic realms. Building upon the literature, we offer a definition and operating principles for an economy of mana, and propose future research directions to build our understanding of an economy of mana with the intention of supporting Māori aspirations and well-being.
\end{abstract}

* Ngāti Porou. Research Fellow, University of Auckland Business School, Auckland, New Zealand. Email: k.dell@auckland.ac.nz

Ngāti Awa, Ngāi Tūhoe. Lecturer, Auckland University of Technology, Auckland, New Zealand.

‡ Ngāruahine. PhD Candidate, University of Auckland Business School, Auckland, New Zealand.

DOI: 10.20507/MAIJournal.2018.7.1.5 


\section{Keywords}

economy of mana, capitalism, mana, alternative economies

\section{Introduction}

The Māori economy has burgeoning potential and growing resources to make a considerable contribution to the Aotearoa New Zealand economy. Current estimates of the Māori asset base are at NZ\$50 billion (Chapman Tripp, 2017), and the Aotearoa public have increasingly come to recognise the significant contribution Māori make to the economy. Cultural and economic development of Māori requires autonomy and self-determination, that is, determining the aspirations and capabilities of Māori, by Māori, in a way that makes sense to Māori (M. Durie, 2003, 2009; KPMG, 2016; G. Smith, Tinirau, Gillies, \& Warriner, 2015). Operating at the intersection of multiple contexts, the Māori economy has inherent tensions that need to prioritise cultural values, while remaining economically viable in an increasingly globalised world. The capitalist and neoliberal system imposed on Māori through colonisation in many ways runs contrary to Te Ao Māori and Māori customary values (Bargh \& Otter, 2009). This paper suggests ways in which we, as Māori, can reshape, reimagine and set new objectives to achieve our aspirations as Māori within alternative economies (Bargh \& Otter, 2009; G. Smith et al., 2015).

The economy of mana (Hēnare, 2011, 2014, 2016), we argue, is one system that can offer insights into new ways of organising and shaping economies. Developed pre-colonisation in the context of a non-monetary system, Māori economic understanding was, and still often is, quite different from the Anglo-Western economic paradigms introduced in early colonial Aotearoa. Contrary to Anglo-Western exchange systems that seek to create shareholder value to maximise individual wealth and profit in the market, traditional Māori economies were based on wealth distribution, rather than wealth accumulation (Hēnare, 2014).

In this paper, we bring together literature pertaining to "the concept of an economy of mana", which has drawn largely on traditional customs and contexts. The first two sections of the paper outline the traditional Māori economic environment that existed pre-colonisation; a conceptualisation of mana follows. We then offer a definition and set of principles of the economy of mana. Next, we explore contemporary economic issues for Māori, considering some of the complexities inherent at multiple intersections of the economy. Building on this foundation, we sketch out a contemporary research agenda that can guide the development of alternative economies to better support Māori aspirations across cultural, social and economic realms.

\section{Traditional Māori economy}

This section provides a context of traditional values and practices of Māori society from which the economy of mana centres its philosophical position. Māori kin groups and the impetus behind economic survival relied on the dynamic and fluid nature of the traditional tribal ecosystem (Ballara, 1998; Metge, 1990; Petrie, 2006). Kin-based groupings made up the social organisation of Māori society, where individuals could affiliate to ancestral lines from various iwi-hapū-whānau kinship groupings based on whakapapa or genealogical descent from an eponymous ancestor.

Māori social organisation is not a fixed hierarchy; rather, it is more complex, dynamic and evolving. Kin ties were activated depending on circumstances of the time and were most often galvanised for support in times of crisis (Hēnare, 
1988). By way of illustration, within hapū, whānau expansion occurred naturally over generations, causing split-offs as a population reached a capacity to enable self-regulation and the formation of independent working units. Thus, a new autonomous hapū would form. By nurturing the original kinship link through established tikanga or relational processes, alliances and coalitions could be developed when external pressures such as shortage of resources or warfare threatened survival. Petrie (2006) affirms "the feasibility of this social structure and the inherent link between individuals, whānau, hapū, and iwi allowed for a variety of regroupings in the face of social, political or economic stress" (p. 13). Māori society was in a state of constant flux.

Māori relationships with each other held the system together, governing the use of and access to resources. Access to resources focused iwi, hapū and whānau attention and energies on nurturing relationships and genealogical alliances. Distinct and defined physical land boundaries tended to be cast aside for a dynamic system involving relational processes. Positive relationships with neighbours and close allies allowed privileged access to resources. Alternatively, negative relationships created the reverse. Relationships helped to create a society of co-existence and peace, interspersed with times of war and battle (Best, 2001). Relational rules were characterised by (a) a reverence for the total creation as one whole; (b) a sense of kinship with fellow beings; (c) a sacred regard to the whole of nature and its resources as being gifts from the gods; (d) a sense of responsibility for these gifts as the appointed stewards, guardians and rangatira; (e) a distinctive economic ethic of reciprocity; and (f) a sense of commitment to safeguard all of nature's resources for the future generations (Waitangi Tribunal, 1992, p. 97).

A traditional Māori economy evolved as a dynamic system allowing for continuous creation, accepting and enabling creative transformative behaviours (Hēnare, Lythberg,
Nicholson, \& Woods, 2017; Royal, 2003). The Māori worldview centres itself around a network of values that interplay and enact with each other. E. T. Durie (1994) refers to these values in Māori traditional society as being governed by conceptual regulators. These principles form the foundations for Māori social order. Many authors write of these values underpinning Māori society; they include, but are not limited to, mana, tapu, utu, whanaungatanga, mauri and kaitiakitanga (Bowden, 1979; E. T. Durie, 1994; M. Durie, 1985, 2003; Hēnare, 2011, 2014; Marsden, 1992; Marsden \& Henare, 1992; Pere, 1982; Spiller, Erakovic, Hēnare, \& Pio, 2010).

The production and consumption of goods and services was a pragmatic and tangible part of traditional Māori economic models (Petrie, 2006; Puckey, 2011). However, the market existed within the social realm whereby the community kinship structures both drove trade and were the purpose for its existence. Commercial relationships were not separate economic, ecological, political, social and spiritual spheres but fused together as one in a Māori exchange system (Hēnare, 2011; Metge, 2002; Royal, 2003; Spiller, 2010; Spiller et al., 2011). Māori did not consider the exchange of goods and services as an isolated transaction; instead, layers of relational interactions and exchanges emerged from economic agreements and commercial contracts (Nicholson, Woods, \& Hēnare, 2012; Petrie, 2006; Puckey, 2011; Spiller et al., 2010).

\section{The philosophy and practice of mana}

Many philosophers, theologians, academics and cultural specialists have tried to offer succinct definitions of mana. Its abstract, intangible and enigmatic nature makes it an elusive concept, difficult to define concisely. Shirres (1997) defined mana as "the realisation and actualisation of tapu" (p. 53); Moorfield (2004) interpreted it as "a supernatural force in a person, place or 
object" (p. 238); and Pere (1982) described mana under many labels: "a psychic influence, control, prestige, power, vested and acquired authority and influence, being influential or binding over others" (p. 36). Reverend Māori Marsden called it a "spiritual authority and power" (Royal, 2003, p. 4); and Royal (2006), redefining mana for a modern context, described it as a "quality, energy or consciousness in the world which can be harnessed and expressed in human activities through acts of generosity and wisdom" (p. 8). Based on these explanations, Dell (2017) defines mana as "a potent human state with the profound ability to impact upon, affect and transform the lives of others" (p. 89). This definition becomes a central tenet for understanding the purpose of the economy of mana.

Mana has a dynamic and transformational quality (Bowden, 1979). It is described as being, ascribed or achieved (E. T. Durie, 1994; Mahuika, 1992); enhanced or decreased by achievements (or non-achievements) (E. T. Durie, 1994), and rising and falling over both time and space; for example, one's mana may only pertain to a specific region, speciality, industry or group of people at a particular time (E. T. Durie, 1994; Salmond, 2009). Ascribed mana explains, through fortunate and esteemed whakapapa, how a person's mana is automatically assumed. However, as an achievement-oriented concept (Bowden, 1979), only through the enactment of dignified behaviour, extraordinary achievement and momentous actions will a person's or community's mana be preserved and enhanced.

Mana derives from the source of tapu-of potentiality for power; thus, in all cases, it has spiritual origins (Hēnare, 2001; Shirres, 1997; Tate, 2010). However, authors describe various sources of mana (E. T. Durie, 1994; Hēnare, 2001; Royal, 2003; Shirres, 1997; Tate, 2010), which usually fall into four separate yet interlinked categories, shown in Table 1.

Together these four sources of mana make up a theory of realising Māori potentiality. Mana atua denotes mana as metaphysical, cosmic, spiritual and divine; something "coming from the gods" (Mahuika, 1992, p. 45), and coming "down the descent lines as a gift of power from Io-matua-te-kore, Tane-nui-ārangi, Tū-matauenga" (Stirling, 1981, p. 205). Mana tūpuna is ancestral power, inherited from historical and past sources. For example, some families are known for their exceptional ability, traits and skills distinctive to certain areas. "Ko te mana i ahau no ōku tūpuna nō tuawhakarere" ("my strength comes from my ancestors from long ago") (Brougham, Reed, \& Karetu, 2012).

Mana whenua is power and authority attached to land. Te Aka Mãori Dictionary defines this as "territorial rights, power from the land, authority, jurisdiction over land or territory ... power associated with possession and occupation of tribal land" (Moorfield, 2005, p. 96). Emphasised by Pere (1982), mana is most effective when people are in their own

TABLE 1 Dimensions of mana

\begin{tabular}{lll}
\hline Mātauranga Māori & Interpretation & Descriptions \\
\hline Mana atua & $\begin{array}{l}\text { Divine power, from a universal } \\
\text { source }\end{array}$ & $\begin{array}{l}\text { Spirituality; universal } \\
\text { connectedness }\end{array}$ \\
Mana tūpuna & $\begin{array}{l}\text { An inherited power, from a } \\
\text { historical source }\end{array}$ & $\begin{array}{l}\text { Genetic influences; historically } \\
\text { developed processes }\end{array}$ \\
Mana whenua & $\begin{array}{l}\text { A terrestrial power, from a localised } \\
\text { source }\end{array}$ & $\begin{array}{l}\text { Influence of environment; } \\
\text { sociological situation } \\
\text { Mana tangata }\end{array}$ \\
& $\begin{array}{l}\text { Personal power, from an inner } \\
\text { source }\end{array}$ & $\begin{array}{l}\text { Personality; temperament, } \\
\text { unique individual attributes }\end{array}$ \\
\hline
\end{tabular}

Source: Dell (2017, p. 91). 
context, papakāinga or tūrangawaewae. Mana tangata is the authority and power attained through personal attributes and individual talents earned through the active expression of positive actions and achievements. Tate (2010) also reflects on the empowerment of individual mana tangata through exercising the mana of the collective. The four sources act as an interrelated system, or an exchange of interactions that co-evolve and shape each other to produce unique combinations of individual and group mana. In this way, mana is not absolutely determined by one source; it combines in unique and inimitable ways, ultimately expressed in human behaviour and activities.

\section{Economy of mana}

The structure and relational underpinnings of traditional Māori society provide the foundation to the economy of mana. The economy of mana concept was coined by Hēnare (2011, 2014, 2016) and has the following themes: (a) it emanates from a Māori worldview and is informed by traditional Māori economics; (b) it is inspired by four well-beings_-spiritual, ecological, kinship, economic; (c) it is embedded in the ecological system that sustains it; (d) it requires a multidisciplinary approach to its research; (e) it is a system that is capable of reorganising itself to create new futures; and (f) it manifests as reciprocity and gift exchange.

The work of Hēnare builds on both Hyden's (1980) economy of affection and Mauss's notion of gift economies (Mauss \& Halls, 2014); however, its principles and underpinning themes are based on traditional Māori values and understandings of the economy. Therefore, the economy of mana, although a nascent body of literature, is founded on mātauranga Māori and thus premised on well-established domains of enquiry within the wider Māori literature (for a more in-depth discussion on (a) traditional Māori economies, see Firth, 1929; Petrie, 2006; Puckey, 2011; Royal, 2003; (b) well-beings, see Roche, Haar, \& Brougham, 2015; Spiller, 2010; Spiller et al., 2011; Nicholson, Spiller, \& Pio, 2017; and (c) mātauranga Māori, reciprocity and gift exchange, see Ahu, Hoare, \& Mamari, 2011; Bishop, 1999; E. T. Durie, 1994; Henry \& Pene, 2001; Mane, 2009; Metge, 2002; Pihama, Cram, \& Walker, 2002; L. Smith, 1999).

As an exchange system, the economy of mana emphasised the notion of increasing, manifesting and protecting mana within people (Hēnare, 2001; Marsden, 1992). Taking into account our previous definition of mana, the economy of mana is a system that manifests and cultivates a potent human state that can affect and transform the lives of others. Therefore, we provide a definition of the economy of mana as:

an economic system in which decisions regarding investment, production, consumption and wealth distribution are influenced by the interplay of mana-enhancing interactions between people and the environment.

The literature on mātauranga Māori, mana and the traditional Māori economy has led to our development of a list of associated principles and key economic ideas of the economy of mana, shown in Table 2.

\section{How people make decisions}

The fundamental premise of the economy of mana is that mana-enhancing behaviours influence the decisions and choices people make. Mana is measured through the assessments of others. A person or group cannot claim to have mana; their mana is credited, recognised and endorsed by others. Usually, accumulating mana is the extent to which a person provides, supports and gives to others, or directs their personal success towards the wider collective. Shirres (1997) highlights the connection between mana and generous achievement: "The real sign of a person's mana or tapu is not that person's power to destroy other people, but 
TABLE 2 Principles of an economy of mana

\begin{tabular}{lll}
\hline $\begin{array}{l}\text { How people make } \\
\text { decisions }\end{array}$ & $\begin{array}{l}\text { Principle 1 } \\
\text { Principle 2 } \\
\text { Principle 3 } \\
\text { Principle 4 }\end{array}$ & $\begin{array}{l}\text { increases the collective good } \\
\text { intergenerational long-term outlooks } \\
\text { mandated and authorised by the people } \\
\text { guided by mana-enhancing behaviours }\end{array}$ \\
$\begin{array}{lll}\text { How people } \\
\text { interact }\end{array}$ & $\begin{array}{l}\text { Principle 5 } \\
\text { Principle 6 }\end{array}$ & $\begin{array}{l}\text { relate through shared experiences } \\
\text { desire to maintain a sense of belonging and connection } \\
\text { with each other }\end{array}$ \\
$\begin{array}{lll}\text { How the economy } \\
\text { works as a whole }\end{array}$ & Principle 7 & $\begin{array}{l}\text { interacts with the four well-beings: spiritual, ecological, } \\
\text { kinship, economic } \\
\text { focus on wealth distribution (as opposed to wealth } \\
\text { accumulation) } \\
\text { the world provides abundance (as opposed to scarcity } \\
\text { and competition) } \\
\text { the entire world is a kinship network of all living things }\end{array}$ \\
& Principle 9 \\
\hline
\end{tabular}

that person's power to manaki or care, to protect and look after other people" (p. 47). The choices people make are based upon whether their mana is upheld, maintained and grown.

Power and authority are two notions related to mana and how it manifests with people (Royal, 2003). Power is the ability or capacity to do something; authority is having the right or mandate to do it. The distinction is important because while a person may have the power to do something, from a mana perspective, they must first have authority. Mana does not act independently or autonomously; it is the lawful, sanctioned and authorised permission to act on the behalf and the will of others. The power-authority interplay impacts decisionmaking where actions need to be sanctioned by the community or those affected.

\section{How people interact}

Mana-enhancing behaviours became the driving force between interactions. Preserving one's mana was crucial and it dictated the processes and practices of interaction. The exchange was offered in the spirit of enhancing the mana of a person or peoples (Mead \& Mead, 2003; Metge, 2002). However, a sense of obligation was also generated, "for every gift another of at least equal value should be returned" (Firth, 1929, p. 406). An obligatory relationship was created with the receiver, who could feel indebted until, at a future point, he or she could return the act of generosity. The relational state of the receiver has become one of imbalance. Māori made concerted efforts to return relational states to one of balance. Once reciprocity is enacted by the receiver, a positive cycle is generated, their mana also becomes enhanced and returned to a harmonised state of relational equilibrium (Ahu et al., 2011; E. T. Durie, 1994; Firth, 1929; Metge, 2002; Patterson, 1992; Quince, 2016; Salmond, 2009).

Rangatira were seen to be bearers of high levels of mana. Rangatira acquire skills that facilitate the right conditions for mana to flourish, but not the mana itself, which is a spiritual endowment unique to each person. Access to resources and providing for people was the primary source for rangatira to accumulate mana. The more a chief could acquire food through accessing land resources, assets and intertribal networks, the more people could be fed, which in turn increased chiefly mana and attracted a larger following (Petrie, 2006). Defined by an ability to nurture and maintain 
the well-being of his people, a chief achieved mana through exceptional leadership capabilities of persuasion, influence, authority, prestige and charisma. Rangatira needed opportunistic and innovative leadership skills to access and maintain resources and food security. The ability to form alliances relied on chiefly mana. Tribes with mana attracted alliances. Economic prosperity through land and influence leveraged partnerships, contracts and negotiations with other tribes. Thus mana had an accumulative effect that tended to perpetuate itself. Failure by a chief to provide economic and political stability diminished his mana and followership. Upholding mana determines a particular behavioural orientation and the nature of interactions for the tribe.

\section{How the economy works}

Relationships embedded in an economy of mana are not solely confined to human relationships: "individuals; communities; the individual and the collective; past, present and future generations; people and atua (gods); and people and the natural world" (Jones, 2014, p. 191) were also accounted for. Māori conceptualise their relationship with the entirety of their world and with each other. The cosmos, according to Māori, unfolded itself as a gigantic system of kinship, between plants, fish and people (Johansen, 1954).

The intent of producing, distributing and consuming in the economy of mana is underpinned by different principles than those offered by mainstream economics. The economy of mana results from the melding of two words: mana and economy. Economy and economics is a subject developed in the Anglo-West and generally explains economic activities (production, distribution and consumption). It aims to describe how individuals achieve maximum utility under the condition of resource scarcity and constraint, and how society can reach maximum welfare under the same condition (Hausman, 2008). The definition speaks to scarcity and constraints of available resources, insufficient to satisfy all needs and wants. However, the economy of mana is stimulated by values of giving and abundance instead of ones that view resources as scarce.

\section{The modern Māori economy}

There is an increasing Māori focus on cultural and economic development to realise the aspirations and capabilities of Māori (KPMG, 2016; Māori Economic Development Panel, 2012; Nana, Kahn, \& Schulze, 2015; G. Smith et al., 2015). Unleashing the potential of the Māori economy is viewed as an integral part of realising those aspirations. Interest in Māori economic development has come from a number of areas, including Māori- and iwi-driven initiatives, government strategy and independent corporations (Chapman Tripp, 2017; Gibson, 2015; KPMG, 2016; Māori Economic Development Panel, 2012; G. Smith et al., 2015).

As noted above, the Māori economy has most recently been estimated at $\$ 50$ billion (Chapman Tripp, 2017). This figure is useful to the extent that it gives some indication about the nature of the resources that can be drawn upon in attempts to improve and further enhance social, cultural and economic conditions for Māori (Nana et al., 2015). Reports highlight that Māori assets, which include Māori trusts, Māori incorporations, Māori employers and self-employed Māori, are heavily based in land and marine resources (Chapman Tripp, 2017; Nana, 2012; Nana et al., 2015). Māori land trusts and incorporations operate mostly within the agriculture sector (Nana, Stokes, \& Molano, 2011), through farming and forestry, with approximately $40 \%$ ownership of forestry assets and $50 \%$ ownership of the fishing quota in Aotearoa (Chapman Tripp, 2017; Harmsworth \& Awatere, 2013).

Media, commercial and political interest has centred on increasing Māori productivity (Nana et al., 2011). Attention to the large sum of assets 
under Māori control has raised the profile of the Māori economy and Māori business (Statistics New Zealand, 2012) and positioned it as a success story that is triumphing from one leaping victory to the next (Hayes, 2015). Yet, consistent media emphasis on the sums awarded by the Waitangi Tribunal have worked to signify settlements as key to Māori economic growth (McCreanor et al., 2011; Rankine et al., 2014). McCreanor et al. (2011) suggest that such an emphasis serves to minimise Māori economic achievements and challenge the legitimacy of Māori business within Aotearoa. Contrary to this media emphasis, actual figures indicate that tribal businesses and Māori land trusts and incorporations make up a minority of this asset base, from an estimated $\$ 12.5$ billion of a $\$ 42.6$ billion asset base in 2013 (Nana et al., 2015 ) to approximately $\$ 15$ billion of a $\$ 50$ billion asset base in 2016 (Chapman Tripp, 2017).

Significantly, the Māori economy has drawn some criticisms and cautions. A large percentage of the asset base represents Māori-owned assets rather than return or income generated by those assets. Consequently, these fixed assets return only minimal profits and revenue to Māori. Considering the socio-economic disadvantages and inequality gaps between Māori and the rest of the Aotearoa population, emphasis on asset development to provide income growth and increase wealth distribution to Māori has become a strategic focus for future planning (Nana et al., 2011). These concerns have also been reflected in media commentary (Dinsdale, 2015; Gibson, 2016). Nana et al. (2015) have argued that based on economic metrics, the predominantly land-based nature of Māori assets has yielded below-average productivity. However, recent evidence of diversification into areas such as geothermal, digital services, tourism and housing (Chapman Tripp, 2017) coupled with Māori aspirations to further diversify (KPMG, 2016) may remedy this issue.

In the contemporary context, the challenge to define and justify the distinctiveness of the Māori economy and Māori business is evident
(Dell, Mika, \& Warren, 2017). The Māori economy has been described as "interconnected with the New Zealand economy", yet with "unique aspects" (Bargh, 2014, p. 461). Others suggest that it is not separate from the economy at large (Treasury, 2013). It is our view that the Māori economy exists at the intersection of multiple contexts. As a consequence, Māori economies centre cultural values and interests amidst achieving commercial viability within the capitalist system dominating in an increasingly globalised world (Dell \& Houkamau, 2016). Given our histories of adaptation, resistance and resilience (Walker, 2004), the Māori economy boasts a multifaceted nature that functions across a spectrum of Māori-centric, Māori and Anglo-Western-blended and Anglo-Westerncentric contexts (Mika \& O'Sullivan, 2014).

Ruwhiu and Cone (2010) argue that any assessment of Māori economic development requires an understanding of Te Ao Māori. As discussed earlier, the traditional Māori economy was based upon Māori values, relational values, holistic worldviews and a return to equilibrium. In contemporary times, Māori often continue to draw from traditional knowledge and resources to manage their business responsibilities, which are often premised on healthy ecosystems and sutsainable resources. The growing Māori asset base serves to support collective aspirations and sustain well-being within communities based in many instances on customary beliefs and practices (Harmsworth \& Awatere, 2013).

G. Smith et al. (2015) identified two key common characteristics of Māori economic development: a focus on long-term intergenerational planning and sustainability coupled with a holistic approach that considers economic development to be inseparable from social, environmental and cultural dimensions. These characteristics, which derive from $\mathrm{Te}$ Ao Māori, have already been positioned as potential contributors to Aotearoa's economy. For example, Nana (2012) proposes that the long-term intergenerational perspective inherent in a Māori worldview would be beneficial 
for all Aotearoa businesses. Nana (2012) argues that Aotearoa's inability to adequately take a long-term perspective has resulted in poor investments in research and development and infrastructure that would yield long-term benefits. Consequently, tikanga and our cultural distinctiveness have been viewed as a source of competitive advantage for Aotearoa business (G. Smith et al., 2015).

Māori discussions of economic development often reference the need for autonomy and self-determination to achieve Māori aspirations on Māori terms (M. Durie, 2003, 2009; KPMG, 2016; G. Smith et al., 2015). Such concerns become imperative against a backdrop of colonisation, which constitutes a historical and contemporary reality needing explicit acknowledgement, particularly when looking to the future potential of alternative economies (Bargh \& Otter, 2009). The relationship between Māori and the Crown since the settler arrival has been strained, yet continues to evolve through ongoing interactions, negotiations and settlements.

As a consequence of engagement with colonisation, highlighting distinctions between Western economic concerns and those of Indigenous peoples has been a common approach in Māori economic research (Nicholson et al., 2017; Pio et al., 2013; Spiller et al., 2011; Verbos \& Humphries, 2015; Whiteman \& Cooper, 2000). However, this distinction has not gone unchallenged. Recently, researchers Reid and Rout (2016) have argued that such distinctions between Māori traditions and characteristics of Western capitalism are not only exaggerated, but perpetuate a divide between Māori culture and mainstream notions of commerce. Referring to it as "reactionary traditionalism", Reid and Rout (2016) suggest that such a divide frames Māori as lacking economic competencies to govern themselves, and further justifies state paternalism. The authors point to traditions of property rights and possession, tribal governance and leadership traditions that share characteristics of Western capitalism. For example, much has been written about the entrepreneurial inclination of the Māori and our quick adoption of Anglo-Western technologies and fondness for trade (Hēnare, 2003; Henry, 2007; Petrie, 2006; Puckey, 2011; Reid \& Rout, 2016).

Despite Māori ideals and aspirations, globalisation, capitalism and neoliberal policy continue to have a significant influence on the Māori economy. Drawing on Gibson-Graham's work on post-capitalist societies, Bargh and Otter (2009) note that power is everywhere, rather than located in one place, such as capitalism or colonisation. Consequently, Bargh and Otter (2009) argue that to frame neoliberal as hegemonic is to ignore the scope for agency, those who utilise neoliberal policy for their own ends, and the existence of alternative economies. For example, the authors identify how Māori have established organisations to engage in service delivery "for Māori, by Māori” in areas of health and education, effectively utilising neoliberal policies to achieve Māori aspirations (Bargh \& Otter, 2009).

Moving into the future, the Māori economy will need to be both flexible and adaptive to cope with rapidly changing global environments. Responding to environmental changes requires enterprises to constantly scan their surroundings, looking for new ways and alternative paths of continuous and sustainable value creation. Mika (2013) argues that Māori entrepreneurs and small to medium enterprises are likely to be key in producing the economic gains projected for the Māori and wider Aotearoa economies. In the context of Aotearoa, we need to remain cognisant of our histories in looking forward to potential futures.

\section{Where to next?}

Our intention here is not to provide a prescriptive research agenda, but to offer ideas that prompt thinking and to support the visioning of Māori economic futures. Today, the increasing asset base of the modern Māori economy is 
drawing national interest to Māori productivity. It is imperative that Māori develop and grow in ways that align with Māori aspirations, as determined by Māori. We argue that traditional values, such as mana, offer important ways forward that differ in significant ways from the mainstream model. To date, suggestions about how to improve our collective socioeconomic position have focused on achieving success within existing capitalist frameworks. For instance, in a recent report by KPMG, Hon. Te Ururoa Flavell outlined aspirations for Māori in Aotearoa in a range of social, cultural and economic areas:

We want our rangatahi to have good qualifications, we want healthy whānau; warm, dry houses; better jobs; flourishing Māori businesses taking on the world; and we want our assets managed in a way that is consistent with our aspirations for our people, and our own ancestral values of love, respect, dignity, kinship, and integrity. (p. 6)

Similarly, He Kai Kei Aku Ringa, the report of the Māori Economic Development Panel (2012), placed an emphasis on transformation. The report determined that Māori transformation would occur through more jobs, better education and Māori-Crown partnerships. While we support these objectives, it could be argued that the intentions outlined in these reports are achievable within a capitalist system. To simply aim for better educational outcomes and better career prospects without defining, articulating or visioning the preferred economy to achieve that risks perpetuating actions and behaviours common in the capitalist colonial system. This cannot create the kaupapa-driven transformational change that Māori claim to aspire to. Future visioning of preferred Māori economies is currently limited. Therefore, we need to reimagine and redefine our futures based on authentic Māori values, worldviews and capabilities.

We propose that work needs to be done on imagining a utopian shared vision for Māori economic futures. Striving towards a prospering economic future requires the design of a compelling vision. Successful visioning requires imaging vivid imagery that evokes a sense of purpose towards achieving a meaningful destination. The vision communicates what is possible and what is the potential for Māori to achieve desired realities. Work could be accomplished through a series of public workshops, focus groups and project design sessions used to reach some Māori consensus on images for an economic future. This work would need to involve a wide variety of peoples, such as rangatahi, kaumātua, environmentalists, economists, technologists, engineers, poets, visual artists, film-makers and other interested parties to create a reimagined future economic future.

Developing concepts for how the economy of mana currently interacts in society could be observed through some of the Mãori-centric institutions that still exist. Perhaps a closer look at the institutions of kapa haka, tangi and marae that operate at regional, national and global levels is needed; these sub-economies work in their own self-sustaining way, with their own principles of engagement, consisting of their own types of institutions that could be explored to provide initial insights for re-imaging. Defining the value systems, incentive drivers, cycles of production, structures and mechanisms of Māori-centric activities will begin to illuminate alternative paths and means to enriched economic futures. Aspiring towards an economy of mana requires a revisioned future. An important consideration will be the extent to which colonisation continues to restrict our thinking. Consequently, imagining a decolonised economy which is not constrained by the way things are now will be our biggest challenge.

\section{Conclusion}

This paper proposes the concept of an economy of mana as a preferred economic pathway 
to transformative potential for Māori and Aotearoa. This article has examined three time periods: past, present and future. From the past, two frameworks stemming from values of a Māori worldview-the dimensions of mana and the principles of mana-have been offered to underpin an economy of mana. Within the present, the obstacles and barriers of the modern Māori economy that we will need to overcome to get to a desired economic future have been addressed. And lastly, looking towards the future, we propose revisualising Māori economic futures based on an economy of mana rather than a future founded on the status quo of the Anglo-Western framework. The article supports the integration of past, present and future perspectives to create desired Māori economic aspirations.

\section{Glossary}

$\begin{array}{ll}\text { Aotearoa } & \begin{array}{c}\text { Māori name given to the } \\ \text { land that was renamed } \\ \text { New Zealand by settlers } \\ \text { spiritual beings; gods } \\ \text { social units that share a } \\ \text { common ancestor } \\ \text { hapū }\end{array} \\ \begin{array}{ll}\text { Io-matua-te-kore } & \text { supreme being } \\ \text { iwi } & \text { tribal kin group; nation } \\ \text { kaitiakitanga } & \text { the obligation of } \\ & \text { stewardship and } \\ & \text { protection of the } \\ & \text { environment } \\ \text { a row/team/group } & \text { performing haka/waiata/ } \\ & \text { poi (dances, chants, songs, } \\ & \text { some with actions) } \\ \text { a potent human state with } \\ \text { the profound ability to } \\ \text { impact upon, affect and } \\ \text { transform the lives of } \\ \text { others } \\ \text { care, to protect and look } \\ \text { after other people }\end{array} \\ \end{array}$

marae

mātauranga

mauri

papakāinga

rangatahi

rangatira

Tāne-nui-ā-rangi an offspring from Ranginui and Papatūānuku (Sky Father and Earth Mother). An atua that brought knowledge from the sky.

tangata people

tangi

to cry/mourn; mourning rituals

tapu

Te Ao Māori

tikanga

Tū-matauenga potentiality for power

a Māori worldview customs and practices; relational processes an offspring from Ranginui and Papatūānuku (Sky Father and Earth Mother). An atua of war and humans.

tūpuna ancestors

tūrangawaewae place where one has the right to stand

utu

whakapapa the principle of balance and reciprocity genealogy, ancestry, familial relationships; crosses ancestral boundaries between people and other inhabitants in the natural world

whānau family; nuclear/extended family

whanaungatanga the centrality of relationships to Māori life whenua land 


\section{References}

Ahu, T., Hoare, R., \& Mamari, S. (2011). Utu: Finding a balance for the legal Maori dictionary. Victoria University of Wellington Law Review, 42(2), 201-219.

Ballara, A. (1998). Iwi: The dynamics of Māori tribal organisation from c.1769 to c.1945. Wellington, New Zealand: Victoria University Press.

Bargh, M. (2014). A blue economy for Aotearoa New Zealand? Environment, Development and Sustainability, 16(3), 459-470. http://doi.org/ $\operatorname{cg} 6 \mathrm{z}$

Bargh, M., \& Otter, J. (2009). Progressive spaces of neoliberalism in Aotearoa: A genealogy and critique. Asia Pacific Viewpoint, 50(2), 154-165. http://doi.org/cw38s2

Best, E. (1902). Notes on the art of war, as conducted by the Maori of New Zealand, with accounts of various customs, rites, superstitions, \&c., pertaining to war, as practised and believed in by the ancient Maori. Part III. The Journal of the Polynesian Society, 11(3(43)), 127-162.

Bishop, R. (1999). Kaupapa Maori Research: An indigenous approach to creating knowledge. In N. Robertson (Ed.), Maori and psychology: Research \& practice (pp. 1-6). Hamilton, New Zealand: University of Waikato.

Bowden, R. (1979). Tapu and mana: Ritual authority and political power in traditional Maori society. Journal of Pacific History, 14(1), 50-61. http:// doi.org/czvd9q

Brougham, A. E., Reed, A. W., \& Karetu, T. S. (2012). The Raupo book of Māori proverbs. Auckland, New Zealand: Raupo.

Chapman Tripp. (2017). Te Ao Māori: Trends and insights. Retrieved from https://www.chapman tripp.com/Publication \% 20PDFs/2017\%20 Chapman\%20Tripp\%20Te\%20Ao\%20Maori $\% 20-\% 20$ trends $\% 20$ and $\% 20$ insights $\% 20$ E-VERSION.pdf

Dell, K. M. (2017). Te hokinga ki te ükaipō: Disrupted Māori management theory-Harmonising whānau conflict in the Māori Land Trust (Unpublished PhD thesis). University of Auckland, New Zealand.

Dell, K. M., \& Houkamau, C. A. (2016, December). Fire keepers and fire seekers: A dual entrepreneurial strategy for developing indigenous economies in a globalized world. Paper presented at the 30th Australian and New Zealand Academy of Management Conference, Brisbane, Australia.

Dell, K. M., Mika, J. P., \& Warren, L. (2017).
Indigenous entrepreneurial ecosystems: A New Zealand perspective. Academy of Management Proceedings, 2017. http://doi.org/cktf

Dinsdale, M. (2015, February 6). Economic potential mostly untapped. Northern Advocate. Retrieved from http://www.nzherald.co.nz/northernadvocate/news/news/article.cfm?c_id=1503449 \&objectid=11397551

Durie, E. T. (1994). Custom law. Unpublished manuscript.

Durie, M. (1985). A Māori perspective of health. Social Science \& Medicine, 20(5), 483-486. http://doi. org/bmnd48

Durie, M. (2003). Ngā kahui pou: Launching Māori futures. Wellington, New Zealand: Huia.

Durie, M. (2009, June). Toward social cohesion: The indigenisation of higher education in New Zealand. Paper presented at the Vice Chancellors' Forum, 17th Conference of Commonwealth Education Ministers, Kuala Lumpur, Malaysia.

Firth, R. (1929). Primitive economics of the New Zealand Maori. London, England: Routledge.

Gibson, A. (2015, February 6). Prospects appear even brighter for Māori economic renaissance. NZ Herald. Retrieved from http://www.nzherald. co.nz/business/news/article.cfm?c_id $=3 \&$ objectid $=11397182$

Gibson, A. (2016, February 5). Mana and money-the Maori business evolution. NZ Herald. Retrieved from http://www.nzherald.co.nz/business/news/ article.cfm?c_id=3\&objectid $=11585325$

Harmsworth, G. R., \& Awatere, S. (2013). Indigenous Māori knowledge and perspectives of ecosystems. In J. Dymond (Ed.), Ecosystem services in New Zealand: Conditions and trends (pp. 274-286). Lincoln, New Zealand: Manaaki Whenua Press. Hausman, D. M. (2008). The philosophy of economics: An anthology. New York, NY: Cambridge University Press.

Hēnare, M. (1988). Nga tikanga me nga ritenga o te ao Maori: Standards and foundations of Māori society. In The April Report, Part One: Future directions, Royal Commission on Social Policy (pp. 5-41). Wellington, New Zealand: Government Printer.

Hēnare, M. (2001). Tapu, mana, mauri, hau, wairua. A Māori philosophy of vitalism and cosmos. In J. A. Grim (Ed.), Indigenous traditions and ecology: The interbeing of cosmology and community (pp. 197-221). Cambridge, MA: Harvard University Press.

Hēnare, M. (2003). Changing images of nineteenth century Māori society: From tribes to nation 
(Unpublished PhD thesis). Victoria University of Wellington, New Zealand.

Hēnare, M. (2011). Lasting peace and the good life: Economic development and the "Ata noho" principle of Te Tiriti of Waitangi. In V. Tawhai \& K. Gray-Sharp (Eds.), Always speaking: The Treaty of Waitangi and public policy (pp. 261-275). Wellington, New Zealand: Huia.

Hēnare, M. (2014). The economy of mana. In D. Cooke, C. Hill, P. Baskett, \& R. Irwin (Eds.), Beyond the free market: Rebuilding a just society in New Zealand (pp. 65-69). Auckland, New Zealand: Dunmore.

Hēnare, M. (2016). In search of harmony: Indigenous traditions of the Pacific and ecology. In W. J. Jenkins, Ms. E. Tucker, \& J. Grim (Eds.), Routledge handbook of religion and ecology. New York, NY: Routledge.

Hēnare, M., Lythberg, B., Nicholson, A. \& Woods, C. (2017). Te Ohu Umanga Māori: Temporality and intent in the Māori entrepreneurial team. In C. Ben-Hafaīedh \& T. M. Cooney (Eds.), Research handbook on entrepreneurial teams: Theory and practice (pp. 208-230). Cheltenham, England: Elgar. http://doi.org/cktg

Henry, E. (2007). Kaupapa Maori entrepreneurship. In L.-P. Dana \& R. B. Anderson (Eds.), International handbook of research on indigenous entrepreneurship (pp. 536-548). Cheltenham, England: Edward Elgar. http://doi.org/cfqz

Henry, E., \& Pene, H. (2001). Kaupapa Maori: Locating indigenous ontology, epistemology and methodology in the Academy. Organization, 8(2), 234-242. http://doi.org/djbdkq

Hyden, G. (1980). Beyond Ujamaa in Tanzania: Underdevelopment and an uncaptured peasantry. Berkeley, CA: University of California Press.

Johansen, P. (1954). The Māori and his religion in its non-ritual aspects. Copenhagen, Denmark: Ejnarn Munksgaard.

Jones, C. (2014). A Māori constitutional tradition. New Zealand Journal of Public and International Law, 12, 187-204.

KPMG. (2016). Māuirau: Adapting in a changingworld. Retrieved from https://home.kpmg.com/nz/ en/home/insights/2016/05/maui-rau-adaptingin-a-changing-world.html

Mahuika, A. (1992). Leadership: Inherited and achieved. In M. King (Ed.), Te ao huriburi: Aspects of Māoritanga (pp. 42-63). Auckland, New Zealand: Reed.

Mane, J. (2009). Kaupapa Māori: A community approach. MAI Review, 3(1), 1-9.
Māori Economic Development Panel. (2012). He kai kei aku ringa: The Crown-Māori economic growth partnership. Wellington, New Zealand: Te Puni Kōkiri.

Marsden, M. (1992). God, man and universe: A Māori view. In M. King (Ed.), Te ao buriburi: Aspects of Māoritanga (pp. 117-137). Auckland, New Zealand: Reed.

Marsden, M., \& Henare, T. (1992). Kaitiakitanga: A definitive introduction to the holistic world view of the Māori. Wellington, New Zealand: Ministry for the Environment.

Mauss, M., \& Halls, W. D. (2014). The gift: The form and reason for exchange in archaic societies. London, England: Routledge.

McCreanor, T., McManus, A., Moewaka Barnes, A., Rankine, J., Borell, B., \& Nairn, R. (2011). Māori business news in the mass media. Sites: A Journal of Social Anthropology and Cultural Studies, 8(2), 32-56. http://doi.org/ckth

Mead, H. M., \& Mead, S. M. (2003). Tikanga Māori: Living by Māori values. Wellington: Huia.

Metge, J. (1990). Te rito o te harakeke: Conceptions of the whaanau. Journal of the Polynesian Society, 99(1), 55-92.

Metge, J. (2002). Returning the gift: Utu in intergroup relations. Journal of the Polynesian Society, 111(4), 311-338.

Mika, J. (2013). What is the role of enterprise assistance in Māori entrepreneurship? A doctoral study of Māori entrepreneurs. Meiji Business Review, 60, 137-159.

Mika, J. P., \& O’Sullivan, J. G. (2014). A Māori approach to management: Contrasting traditional and modern Māori management practices in Aotearoa New Zealand. Journal of Management \& Organization, 20(5), 648-670. http://doi.org/cktk

Moorfield, J. C. (2004). Te kōhure. Auckland, New Zealand: Pearson Education.

Moorfield, J. C. (2005). Te aka: Māori-English, English-Māori dictionary and index. Auckland, New Zealand: Pearson Longman.

Nana, G. (2012, July 12). Māori economyburden or taonga? Retrieved from http://www. berl.co.nz/in-focus/maori-economy-burdenor-taonga

Nana, G., Kahn, M., \& Schulze, H. (2015). Te ōhanga Māori: Māori economy report 2013. Wellington, New Zealand: Te Puni Kōkiri.

Nana, G., Stokes, F., \& Molano, W. (2011). The asset base, income, expenditure and GDP of the 2010 Māori economy. Wellington, New Zealand: Business and Economic Research Limited. 
Nicholson, A., Spiller, C., \& Pio, E. (2017). Ambicultural governance: Harmonizing Indigenous and Western approaches. Journal of Management Inquiry. Advance online publication. http://doi.org/cktm

Nicholson, A., Woods, C., \&Hēnare, M. (2012).Umanga whanaungatanga: Family business. Journal of Australian Indigenous Issues, 15(4), 36-51.

Patterson, J. (1992). Exploring Māori values. Palmerston North, New Zealand: International Specialized Book Service.

Pere, R. R. (1982). Ako: Concepts and learning in the Māori tradition. Wellington, New Zealand: National Library of New Zealand.

Petrie, H. (2006). Chiefs of industry: Māoritribal enterprise in early colonial New Zealand. Auckland, New Zealand: Auckland University Press.

Pihama, L., Cram, F., \& Walker, S. (2002). Creating methodological space: A literature review of kaupapa Maori research. Canadian Journal of Native Education, 26(1), 30-43.

Pio, E., Waddock, S., Mangaliso, M., McIntosh, M., Spiller, C., Takeda, H., . . Syed, J. (2013). Pipeline to the future: Seeking wisdom in Indigenous, Eastern, and Western traditions. In J. Neal (Ed.), Handbook of faith and spirituality in the workplace (pp. 195-219). New York, NY: Springer. http://doi.org/cktn

Puckey, A. (2011). Trading cultures: A history of the far north. Wellington, New Zealand: Huia.

Quince, K. (2016). Māori disputes and their resolution. In H. Tuso \& M. P. Flaherty (Eds.), Creating the third force: Indigenous processes of peacemaking. Lanham, MD: Lexington Books.

Rankine, J., Moewaka Barnes, A., McCreanor, T., Nairn, R., McManus, A.-L., Abel, S. . . Gregory, A. (2014). Content and source analysis of newspaper items about Māori issues: Silencing the "natives" in Aotearoa? Pacific Journalism Review: Te Koakoa, 20(1), 213-233. http://doi. org/cktp

Reid, J., \& Rout, M. (2016). Māori tribal economy: Rethinking the original economic institutions. In T. L. Anderson (Ed.), Unlocking the wealth of Indian nations (pp. 84-103). Lanham, MD: Lexington Books.

Roche, M. A., Haar, J. M., \& Brougham, D. (2015). Māori leaders' well-being: A self-determination perspective. Leadership, 14(1), 25-39. http:// doi.org/gcz5bt

Royal, T. A. C. (2003). The woven universe: Selected writings of Rev. Māori Marsden. Otaki, New Zealand: Estate of Rev. Māori Marsden.
Royal, T. A. C. (2006, September). A modern view of mana. Paper presented at the Joint Conference of the Australian Psychological Society and the New Zealand Psychological Society, Auckland, New Zealand.

Ruwhiu, D., \& Cone, M. (2010). Advancing a pragmatist epistemology in organisational research. Qualitative Research in Organizations and Management: An International Journal, 5(2), 108-126. http://doi.org/b969cx

Salmond, A. (2009). Hui: A study of Māori ceremonial gatherings. Auckland, New Zealand: Raupo.

Shirres, M. P. (1997). Te tangata: The human person. Auckland, New Zealand: Accent.

Smith, G., Tinirau, R., Gillies, A., \& Warriner, V. (2015). He mangōpare amohia: Strategies for Māori economic development. Whakātane, New Zealand: Te Whare Wānanga o Awanuiārangi. Smith, L. (1999). Decolonizing methodologies: Research and indigenous peoples. Dunedin, New Zealand: University of Otago Press.

Spiller, C. M. (2010). How Māori cultural tourism businesses create authentic and sustainable wellbeing (Unpublished $\mathrm{PhD}$ thesis). University of Auckland, New Zealand.

Spiller, C., Erakovic, L., Hēnare, M., \& Pio, E. (2011). Relational well-being and wealth: Māori businesses and an ethic of care. Journal of Business Ethics, 98(1), 153-169. http://doi.org/ dvph46

Statistics New Zealand. (2012). Tatauranga Umanga Māori: Consultation paper. Wellington, New Zealand: Author.

Stirling, E. (1981). Eruera: The teachings of a Māori elder (A. Salmond, Ed.). Wellington, New Zealand: Oxford University Press.

Tate, H. (2010). Towards some foundations of a systematic Māori theology: He tirohanga anganui ki ètahi kaupapa hohonu mo te whakapono Māori (Unpublished doctoral thesis). Melbourne College of Divinity, Melbourne, Australia.

Treasury. (2013, December). Speech delivered by Vicky Robertson, Deputy Chief Executive of the Treasury, to the Huihuinga Wahine Māori Women Leadership Summit, Wellington, New Zealand. Retrieved from http://www.treasury. govt.nz/publications/media-speeches/speeches/ huihuingawahine

Verbos, A. K., \& Humphries, M. T. (2015). Indigenous wisdom and the PRME: Inclusion or illusion? Journal of Management Development, 34(1), 90-100. http://doi.org/cktq 
Waitangi Tribunal. (1992). The Ngai Tahu sea fisheries report, 1992 (Wai 27). Wellington, New Zealand: Brooker and Friend.

Walker, R. (2004). Ka whawhai tonu mātou: Struggle without end. Auckland, New Zealand: Penguin.
Whiteman, G., \& Cooper, W. H. (2000). Ecological embeddedness. Academy of Management Journal, 43(6), 1265-1282. http://doi.org/cgrvc2 